\title{
Role of the boutique industry in apprenticeship implementation and assessment for supporting the diploma supplement issuance
}

\author{
Agus Hery Supadmi Irianti ${ }^{1, *}$, Nurul Hidayati ${ }^{2}$, Annisa Rafida ${ }^{3}$ \\ ${ }^{1}$ Department of Industrial Technology, Faculty of Engineering, Universitas Negeri Malang \\ ${ }^{2}$ Department of Industrial Technology, Faculty of Engineering, Universitas Negeri Malang \\ ${ }^{3}$ Department of Industrial Technology, Faculty of Engineering, Universitas Negeri Malang \\ "Corresponding author: agus.hery.ft@um.ac.id
}

\begin{abstract}
This study aimed at investigating the role of the boutique industry (1) in the implementation of apprenticeship in compliance with the IQF standards and (2) in the apprenticeship assessment for supporting the Diploma Supplement issuance. The study was descriptive quantitative research. The research population included 17 fashion boutiques in Malang which have offered apprenticeship placements for Fashion Design students in the past 2 years (2016-2017). Results showed that most of the boutiques have fulfilled their roles in the implementation of apprenticeship well, as shown by an average score of $60.80 \%$. Regarding their roles in apprenticeship assessment, none of them has conducted assessment according to the DS requirements although they have assessed student performance during apprenticeship in compliance with the established guidelines.
\end{abstract}

Keywords: boutique industry's role, apprenticeship, assessment

\section{Introduction}

The Diploma Supplement (DS) or Surat Keterangan Pendamping Ijazah (SKPI) is an official statement issued by higher education institutions which accompanies a higher education diploma and contains a record of academic achievement or qualification [1-2]. Students who have met all the requirements for graduation will earn a diploma, degree and SKPI [3-4]. The tertiary education curriculum used in Indonesia is developed based on the Indonesian Qualification Framework (IQF), Each study programme must provide a description of the minimum learning outcomes referring to the IQF [5]. The DS serves to showcase student skills gained during apprenticeship or other completed qualifications from accredited institutions so as to attain recognition in relevant employment [6]. This document must 
provide a description containing valid, easily understood information on the content and status of the competencies each student acquires as an apprentice [7]. Thus, the information on student achievement and competencies required for issuing the DS should be presented in narrative form to show whether or not the assessment made by the industry is in accordance with the standardised procedure [8]. Many apprentices are assigned to work in areas that do not match the desired standard competency requirements. More often than not, their performance is represented only by numerical grades. As a document accompanying a higher education diploma, the DS absolutely requires the informed judgements by apprenticeship mentors who can describe in details the performance of students and the competencies gained. This narrative-based evaluation can outline every single practical skill a student develops using detailed descriptors [9].

Apprenticeship is a compulsory non-educational field course. It is a work-based training programme that aims to give the skills needed to meet workforce requirements [10-11]. The apprenticeship course is an effective way to prepare students to become professional workers in the skilled trades [12]. Through this course, students are expected to have the opportunity to apply their knowledge and skills in the workplace, gain real work experience, and conduct business management analysis.

The boutique industry plays a crucial role in offering apprenticeship placements, assessing student performance and giving recognition for accomplishments. Compelled by this background, it is necessary to explore the boutique industry's role in offering apprenticeship programmes in accordance with relevant competency standards, namely referring to the IQF for the implementation of apprenticeships in the fashion boutique industry. In this study, the role of the boutique industry in supporting the preparation of DS is to provide apprenticeship opportunities for fashion students in 2016-2017 to gain the requisite skills and professional competencies.

\section{Research Method}

This study was descriptive quantitative research. Descriptive research aims at describing existing phenomena both natural and artificial [13]. This study involved a single variable, namely the role of the boutique industry in providing recognition of apprentice qualifications for the purpose of issuing the DS. Data were obtained using a questionnaire containing questions relevant to the research objectives [14]. This study used a questionnaire consisting of a combination of closed-ended and Likert scale questions. The research population included 17 fashion boutiques in 
Malang which have offered apprenticeship placements for Fashion Design students in the past 2 years, namely Silla Moda, YnA Wedding, Iwan Bridal, Dinar Weddover, Andy Sugix, Queen Mozza, Kebaya Priambodo, Rezawu Boutique, Amelia Wedding, Arta Moda, Etyk Kebaya, Reve Couture, Eliza Wedding and Studio Ifan. The samples were selected through saturation sampling. The construct validity of the instrument was established by a panel of experts from the fashion industry and universities. Descriptive statistics were used for data analysis. The data analysis was done through the following steps: 1) calculating the score for each subvariable, 2) recording the scores, 3) averaging out the scores and 4) calculating percentages using the following formula:

$$
D P=\frac{n}{N} \times 100 \%
$$

Where:

$\begin{array}{ll}D P & =\text { Descriptive percentage }(\%) \\ n & =\text { Empirical score (number of points obtained) } \\ N & =\text { Maximum score for each question item }\end{array}$

The level of criteria is set by determining the highest percentage (maximum score $\mathrm{x} 100 \%$ ), determining the lowest percentage (minimum score $\mathrm{x} 100 \%$ ), and finally calculating the class interval.

\section{Results and Discussion}

\subsection{Role of the Boutique Industry in the Implementation of Apprenticeship According to the IQF Standards}

Based on the questionnaire results (responses to the 34 question items), the boutique industry occupies several roles in offering apprenticeship programmes according to the IQF, i.e. planning, implementing and evaluating. The overall performance of the boutique industry in fulfilling these roles is presented in Table 1.

Table 1. Data on the Boutique Industry's Roles within the Apprenticeship Programmes According to the IQF

\begin{tabular}{|l|l|l|l|l|c|c|}
\hline No & \multicolumn{1}{|c|}{ Indicator } & Excellent & Good & Fair & Poor & Total \\
\hline & & $\%$ & $\%$ & $\%$ & $\%$ & $\%$ \\
\hline 1. & $\begin{array}{l}\text { Planning the } \\
\text { apprenticeship programme }\end{array}$ & 0 & 70.6 & 29.4 & 0 & 100 \\
\hline
\end{tabular}




\begin{tabular}{|l|l|l|l|l|l|l|}
\hline & according to the IQF & & & & & \\
\hline 2. & $\begin{array}{l}\text { Implementing the } \\
\text { apprenticeship programme } \\
\text { according to the IQF }\end{array}$ & 17.6 & 58.8 & 23.5 & 0 & 100 \\
\hline 3. & $\begin{array}{l}\text { Evaluating the } \\
\text { apprenticeship programme } \\
\text { according to the IQF }\end{array}$ & 47.1 & 52.9 & 0 & 0 & 100 \\
\hline & Mean & 21.60 & 60.80 & 17.60 & 0 & 100 \\
\hline
\end{tabular}

The calculation data can also be recapped in the following table and diagram.

Table 2. Recapitulation of Data on the Boutique Industry's Roles in Implementing the Apprenticeship Programmes According to the IQF

\begin{tabular}{llc}
\hline No & Category & $\%$ \\
\hline 1. & Excellent & 21.60 \\
2. & Good & 60.80 \\
3. & Fair & 17.60 \\
4. & Poor & 00.00 \\
\hline \multicolumn{2}{l}{ Total } & 100.00 \\
\hline
\end{tabular}

Boutique Industry's Roles in Implementing the Apprenticeship Programmes According to the IQF Standard

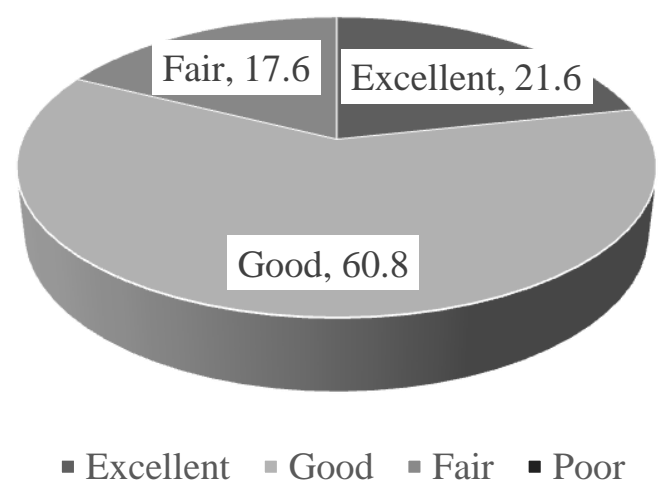

Figure 1. Data on the Boutique Industry's Roles within the Apprenticeship Programmes in Compliance with the IQF 
Table 1 indicates that most of the boutiques have fulfilled their roles well, as shown by an average score of $60.80 \%$ which falls into the 'good' category. In other words, most boutiques have provided and organised apprenticeship training programmes which are in compliance with the IQF standards.

\subsection{Role of the Boutique Industry in the Apprenticeship Assessment for Supporting the Diploma Supplement Issuance}

Based on the responses to the 5 question items in the questionnaire, the boutique industry's roles in assessing student performance during apprenticeship include assessment in compliance with guidelines and assessment according to the DS requirements. The overall performance of the boutique industry in fulfilling these roles is presented in Table 3.

Table 3. Data on the Boutique Industry's Roles in the Apprenticeship Assessment for Supporting the Diploma Supplement Issuance

\begin{tabular}{|l|l|c|r|r|r|c|}
\hline No & Indicator & Excellent & \multicolumn{1}{l|}{ Good } & \multicolumn{1}{l|}{ Fair } & \multicolumn{1}{l|}{ Poor } & \multicolumn{1}{c|}{ Total } \\
\cline { 2 - 7 } 1. & $\begin{array}{l}\text { Assessment in compliance } \\
\text { with guidelines }\end{array}$ & 100 & 0 & 0 & 0 & 100 \\
\hline 2. & $\begin{array}{l}\text { Assessment in compliance } \\
\text { with the DS requirements }\end{array}$ & 0 & 0 & 0 & 0 & 0 \\
\hline & Mean & 100 & 0 & 0 & 0 & 100 \\
\hline
\end{tabular}

The calculation data can also be recapped in the following table and diagram.

Table 4. Recapitulation of Data on the Boutique Industry's Roles in the Apprenticeship Assessment for Supporting the Diploma Supplement Issuance

\begin{tabular}{lll}
\hline No & Category & $\boldsymbol{\%}$ \\
\hline 1. & Excellent & 50.00 \\
2. & Good & 0 \\
3. & Fair & 0 \\
$4 . \quad$ Poor & 50.00 \\
\hline \multicolumn{2}{l}{ Total } & 100.00 \\
\hline
\end{tabular}


Boutique Industry's Roles in the Apprenticeship

Assessment

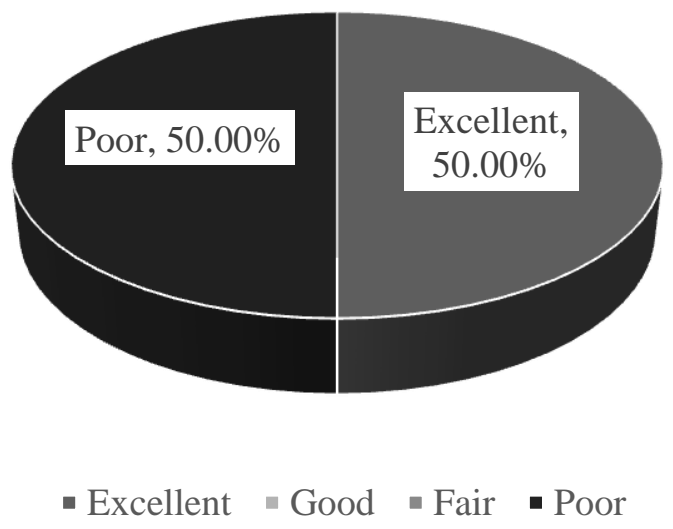

Figure 2. Data on the Boutique Industry's Roles within the Apprenticeship Programmes in Compliance with the IQF

Table 3 indicates that all boutiques under study have conducted assessment according to the established guidelines; half of all the boutiques have assessed student performance during apprenticeship very well, but half of them have performed the apprenticeship assessment poorly. In other words, all boutiques have conducted assessment in compliance with the established guidelines, but none of them has complied with the DS requirements. It is possibly because, unlike in some other countries, the DS is quite a new concept in Indonesia-it was introduced in 2014,

\section{Conclusion}

The research results suggested that all boutiques under study have fulfilled their roles in implementing the apprenticeship programmes properly. However, none of them has conducted assessment according to the DS requirements although they have assessed student performance during apprenticeship in compliance with the established guidelines.

\section{References}

[1] Peraturan Menteri Pendidikan dan Kebudayaan nomor 81 Tahun 2014 tentang Ijazah, Sertifikat Kompetensi,dan Sertifikat Profesi 
Pendidikan Tinggi (online),(https://kopertis3.or.id/v2/2016/01/15/) diakses 15 Agustus 2017

[2] Madalina, C. Diploma Supplement-Instrument of the Quality Assurance Process in the Romanian Higher Education? (2012).

[3] Peraturan Menteri Pendidikan dan Kebudayaan nomor 49 Tahun 2014 tentang Standar Nasional Pendidikan Tinggi.(online), (https://kopertis3.or.id/v2/2016/01/15/), diakses 15 Agustus 2017

[4] Christensen, L. The Bologna Process and medical education. Medical Teacher 26, 625-629 (2004).

[5] Peraturan Menteri Pendidikan dan Kebudayaan nomor 73 Tahun 2013 tentang Penerapan Kerangka Kualifikasi Nasional Indonesia. (online), ((https://kopertis3.or.id/v2/2016/01/15/), diakses 25 Agustus 2017

[6] Watt, I. \& Gregory, H. The Diploma Supplement in Australia. (discussion paper, DEST, Canberra, 2002).

[7] Berg, C. \& Teichler, U. Unveiling the hidden information in Credentials: a proposal to introduce a "Supplement to Higher Education Diplomas". Higher Education in Europe 13, 13-24 (1988).

[8] Vocational skills and competencies made visible - The ASCOT research initiative. 12

[9] Tovar, E. Analyzing the problems of the implementation of the European credit transfer system in a technical university. in T3D11 (IEEE, 2004).

[10]Hamalik, O. Manajemen Pelatihan Ketenagakerjaan. Jakarta: Bumi Aksara (2007).

[11]Hamalik, O. Proses Belajar Mengajar. Jakarta: Bumi Aksara (2007).

[12]Bilginsoy, C. The hazards of training: Attrition and retention in construction industry apprenticeship programs. ILR Review 57, 5467 (2003).

[13] Sugiono. Metode Penelitian Pendidikan Pendekatan Kuantitatif, Kualitatif, dan R \& D. Bandung Alfabeta (2011)

[14]Riduan. Belajar mudah Penelitian Untuk GuruKaryawan dan Peneliti pemula. Bandung: Alfabert.(2004). 
Number : 29.10.1/UN32.5/PB/2018

\section{Certificate of Participation}

Awarded to :

\section{Agus Hery Supadmi Irianti}

who has participated on ICOVET 2018, with the tittle

Role of The Boutique Industry in Apprenticeship Implementation and Assessment for Supporting The Diploma Supplement Issuance.

Chairman of ICOVET 2018

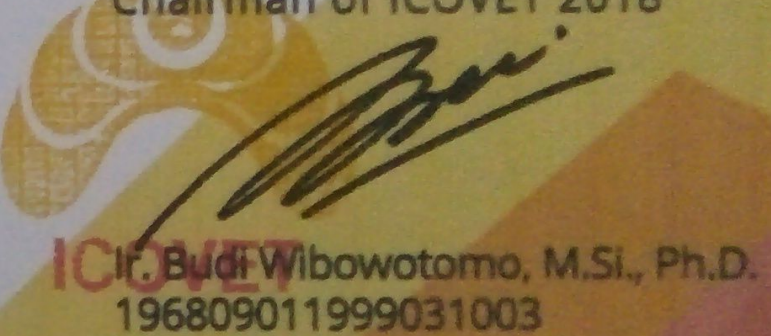

as

\section{AUTHOR}

Malang,

October 27 - 28, 2018

Ijen Suites Hotel 